\title{
The Chaoulli decision: a debate in which physicians must be heard
}

\section{Robert Ouellet}

B See related articles pages 898 and 901

A French translation is available at www.cmaj.ca/cgi/content/full/173/8/896/DC1.

"The Canadian Medical Association supports the principle that when timely access to care cannot be provided in the public health care system, the patient should be able to utilize private health insurance to reimburse the cost of care obtained in the private sector."

$\mathrm{P}$ assed by a majority vote (64\%) on August 17, the above resolution was presented to the General Council of the CMA by physician delegates of the Quebec Medical Association (QMA). Like it or not, the decision rendered by the Supreme Court of Canada in the Chaoulli case may alter profoundly the organization of health care in Quebec ... for the time being. The longstanding debate on the private sector's role in health care has suddenly come to the fore, and the government will soon have to legislate on this matter. The time has come to discuss the means, the parameters and the guidelines. It's hard to imagine that, in this context, physicians would abstain from taking part in a debate that is fundamental not only to their profession, but also to the entire population. Indeed, judging from the results of a survey of Quebec physicians, residents and medical students conducted for the QMA by Léger Marketing in July, the vast majority of patients $(85 \%)$ discuss the organization of our health care system with their physicians. And $93 \%$ of the survey respondents want the QMA to be actively involved in developing new policies in this area. The message is clear.

Despite the fact that the Supreme Court decision applies only in Quebec, 64\% of physician delegates to the CMA's General Council voted in favour of the resolution, which isn't surprising given that the problem raised concerns all Canadians. The lack of access to services penalizes both the population and the medical profession across Canada. Everyone is searching for solutions to improve our health care system, and the Supreme Court is forcing an in-depth debate on an avenue worthy of consideration. Everyone feels the weight of this issue.

If things were improving on the health care front, the Supreme Court would never have intervened. So it's now vital to broaden the scope of the debate as much as possible; beyond the legal and ideological considerations, problems with the organization of our health services must also be settled. We must all do our part to implement the best possible solutions. Despite recommendations issued over the years by countless investigating commissions and working committees, the problem of access has not gone away. The resolution submitted by the QMA specifically aims to resolve this problem. Traditional avenues have led us nowhere; we must find another way. Opening up the private sector, with the proper guidelines and supervision, may be promising. But we must study this issue with the kind of open mind that such an important debate warrants. At the same time, we cannot ignore the fact that Canada is virtually the only industrialized nation to have a public monopoly on the delivery of necessary medical services. Other countries have chosen a different approach, with meaningful results in many cases: France, England, Germany, Denmark and Sweden. Are we the only ones to be right? Can we not learn from the experience of other countries whose values are so much like our own?

The QMA-Léger Marketing survey revealed that over 3 out of 5 respondents are in favour of the intervention of the private sector in our health care system. This being said, there are many possibilities to consider. Very few people believe that a completely unrestricted private system should be allowed to develop alongside the public system. However, most medical professionals (94\% of respondents) believe that it is their duty to suggest adjustments regarding the role of medical clinics in dispensing first-line services. Recommendations from the Ménard report (http://publications.msss.gouv .qc.ca/acrobat/f/documentation/2005/rapportmenard.pdf) on the survival of Quebec's health care system suggested utilizing the private sector under proper government supervision. Basically, the private sector would support the public sector for the purposes of providing greater access to health care services. A dominant view emerges: most health professionals and representatives of the public declare that they are attached to the public health care system and see the private sector only as a complement to the public system, not as a competitor and certainly not as a substitute.

The CMA General Council vote convention calls on the profession to become fully involved in the upcoming debate. The medical profession has much to contribute in this area, and our most fervent wish is to unite our ideas and our strengths so that Canadians can benefit from a highquality and accessible health care system that makes the most of all available resources.

Dr. Ouellet is President of the Quebec Medical Association, Montréal, Que.

Correspondence to: Dr. Robert Ouellet, Quebec Medical Association, 380 St-Antoine Ouest, bureau 3200, Montréal, Que. H2Y3X7; chantal.mantha@amq.ca 